\title{
TOWARDS IMPLEMENTING A NEW MARITIME ACCIDENT REPORTING ANDANALYSIS SYSTEM IN NAMIBIA
}

\author{
Moses Amweelo ${ }^{1 *}$ \\ *Corresponding Author: -
}

\begin{abstract}
: -
When Namibia became an independent state in 1990, the Republic of Namibia inherited the Merchant Shipping Act No. 57 of 1951 from the old South Africa regime. The Merchant Shipping AmendmentAct,1991 was signed into force "in order to adjust its provisions in view of the independence of Namibia; and to provide for incidental matters. "Maritime issues were placed under theauthorityof the Ministry of Works and Transport, however, without any particular defined body, except Department of Transport, to enforce the provisions of the amendment Act (The MerchantShipping ActNo. 57 of 1951, as amended in 1991). In 1995 the Directorate Maritime Affairs was established to be the Ministry's executing body, and one of the first tasks taken on in order to get a firm picture of the maritime legal situation was to carry out an analyse of the Merchant Shipping Act. According to Professor Hilton Staniland of the University of Natal, in his executive summary he states among others: 'The 1951 Act is out of date and places, in particular, the safety of life and ships at sea, the protectionof the marine environment provide Namibia a disadvantageous position as far as international maritimetransport and trade is concerned. It is interesting in this connection to note the concerns at that time expressed by representatives from the fishing industry: 'The industry therefore (not sufficient Namibianswith certificates) favours the amendment of section 83 of the Merchant Shipping Act1951 in orderto provide for the more ready recognition of foreign certificates. Section 83 of the Act opens up for allowing holders of foreign certificates to serve on board Namibian ships. In the meantime thenewlyestablished Directorate Maritime Affairs should make a choice: Either hastily accede to the InternationalMaritime Organisation (IMO) Conventions or first ensure that relevant instruments wereinplaceandthenwork for the accession to the Conventions. It was decided to ensure that the Directorate would be ableto enforce the Conventions and then accede. The aims of the directorate are: to ensure the safety of life and property at sea; to prevent and combat pollution of the marine environmentby shipsand to promote the maritime interests of Namibia.
\end{abstract}

Key Words: The Maritime Legal Situation, The Protection of the Marine Environment, CombatMarine Pollution, Life Saving Appliances, The Safety of Ships at Sea, Accident reporting system

\section{() (\$) (1)}




\section{INTRODUCTION}

This paper concentrate on the two first objectives, although safety at sea and protection of the marine environment is absolutely in the interests of Namibia. At this early stage of the new maritime administration, it was clearly that a new maritime legislation had to be developed, basically in line with Professor Staniland's recommendations, however, also on the ground that operational procedures in line with a modern maritime industry, had to get in place, if the administration should have the slightest chance to efficiently enforce the law. Thus, representatives from the fishing and shipping industry were invited to participate in the development of maritime legislation. Following the Conventions were identified as priorities for the legislative work:

- Convention on the International Regulations for Preventing Collisions at Sea (COLREG), 1972;

- International Convention for the Safety of Life at Sea (SOLAS), 1960 and 1974;

- International Convention on TONNAGE Measurement of Ships, 1969;

- The International Convention for the Prevention for Pollution from Ships, as modified by theProtocol of 1978 relating thereto (MARPOL 73/78);

- International Convention on Load Lines (LL), 1966;

- International Convention on Civil Liability for OIL Pollution Damage (CLC), 1969;

- International Convention on the Establishment of an international Fund for Compensation forOil Pollution Damage (FUND), 1971;

- International Convention on Standards of Training, Certification and Watchkeeping forSeafarers, (STCW 1978 as amended in 1985

- The International Convention on Standards of Training, Certification and Watchkeeping forFishing Vessel Personnel, 1995.

- Admiralty Act/Arrest of Ships;

- International Convention on Oil Pollution Preparedness, Response and Cooperation (OPRC),1990;

- International Convention on Maritime Search and Rescue (SAR), 1979

Since then, Namibia has acceded to COLREG, SOLAS and TONNAGE. All above listed Conventions are safety related in their respective areas, and fundamental for the people working on board ships or vessels.

\section{Objectives}

In order to be able to establish a clear picture of the situation when discussing a new maritime accidentreporting system, it is important to know the following:

- Present legislation related to the maritime industry;

- Required legislation enabling an enforcement of a reporting system;

- The present composition of the fleet registered under the Namibian flag;

- Expected future fleet under the Namibian flag;

- Present and required administrative instruments to handle a reporting system;

- Evaluation of what a reporting system shall be used for and consequences of received reports both for the administration and the party producing the report.

The objectives will therefore be to establish a reporting regime supporting an acceptable safety standardon board ships and vessels, and at the same time makes it possible through analysis of reported accidents to establish the cause of the accident, and what remedies are required to avoid or to minimize the chances for similar accidents to happen again (African Newsletter on Occupational Health and Safety, Volume 10, number 1 April 2000). If such a reporting system shall be efficient, experience has proved that it is not enough to have the laws and regulations in place for enforcing the reporting system. There must also be an understanding in the industry itself of the importance of the reporting system. The managements, on board and ashore, must realize the benefits which a fleet with no or a minimum occurring accidents represent. The reporting system shall not be another paper flow for new files only, neither for the maritime industry nor the administration.

\section{The problem}

In order to understand the complexity of the problem, it is necessary to comprehend the legislative situation in relation to the maritime industry concerned. Hence, it is imperative to have a full understanding of the actual industrial situation, in view of the fact that the Republic of Namibia, during 26 years period shall build up all vital functions for a modern society under the Constitution. It shall be noted that Namibia traditionally has been an agricultural and mining country, with no maritime traditions or culture to build on. The new Republic of Namibia only 26 years ago took on the responsibilities to execute her authority as a coastal state;-with a coast line of approximately 1500 kilometres stretching from the baseline out to 200 nautical miles from its coast into the Atlantic Ocean exclusive economic zone (EEZ) as prescribed by the United Nations Convention on the Law of the Sea over which a state has special rights regarding the exploration and use of marine resources, including energy production from water and wind (United Nations Convention on the Law of the Sea). Considering the potential resources this coastal and ocean area represent, and further considering the aspirations this new role as a coastal state may create, any regulatory approach to reporting systems and requirements must be viewed in light of that, and the commitments accepted when acceding international maritime conventions. As a matter of fact, the government has through the Ministry of Works and Transport and the Directorate Maritime Affairs, committed itself to ensure that Namibian waters and ports shall not be a safe haven for sub-standard shipping. 


\section{Methodology}

To reach a conclusion of value on which a practical solution can be built it is necessary to ask following questions for elaboration and summary:

- What kind of control and reporting system is in force in the Namibian industry as such, toprotect the labour force against accidents; and

- What consequences does this system represent for the companies, managements, supervisorsand the individual employees concerned?

- Does present legislation governing the land based industry also cover the maritime industry?

- Which legislative instruments are available for the maritime sector providing legal support fora reporting system as wanted?

- What do the maritime conventions require with regard to accident reporting?

- Which other international agreed instruments exist for implementation and adoption by theindustry?

- What kind of accidents are most frequently observed in the maritime industry?

Again, we are facing the fact that Namibia must build up an important function from the beginning. However, the situation represents an advantage: By building up from the beginning we can learn from existing systems in other countries and avoid unnecessary failures. Before any other issues shall be addressed, we will have a closer look at the maritime industry and the fleet.

\section{Maritime Regulations}

The Merchant Shipping Act No. 57 of 1951 as amended in 1991, Chapter V, provides regulations concerning safety of ships and life at sea. Part IV, sections 255-263 is particularly handling accidents at sea; but what shall be noted is that the Act does not provide a particular regime for reporting accidents at sea, except for section 259 which states: "The owner or master of any ship-

a. Which has been lost, abandoned or stranded; or

b. Which has been seriously damaged or has caused serious damage to any other ship; or

c. On which any casualty resulting in loss of life or serious injury to any person has occurred; or

d. Which has been in a position of great peril either from the action of some other ship or anyother reason; or

e. Which, having left any port in the Republic has put back to that port; or

f. Which has fouled or done any damage to any harbour, dock or wharf or to any lightship, buoy, beacon or sea mark,

Shall within twenty-four hours after the happening of the event, or as soon thereafter as possible, reportit to the nearest proper officer in the form prescribed. The act, through the power of the Minister and his authorized officers, may establish a reporting regime deemed necessary for the maritime administration to maintain control of the safety situation in the fleet. When acceding to the SOLAS Convention, the maritime administration of Namibia has committed itself also to comply with ChapterI, Part C, Regulation 21: "Each administration undertakes to conduct an investigation of any casualty occurring to any of its ships subject to the provisions of the present convention when it judges that suchan investigation may assist in determining what changes in the present regulations might be desirable."It follows from above that contracting governments undertakes to supply the organisation (IMO) with pertinent information concerning the findings of such investigations. The most significant document with regard to safety on board, safety management and reporting requirements, is the International Management Code for the Safe Operation of Ships and for Pollution Prevention. (The International Safety Management Code). The International Shipping Federation/International Chamber of Shipping - ISF/ICS - has produced "Guidelines on the application of the ISM Code". In the Code's Paragraphit is stated: "Every Company should develop, implement and maintain a safety management system (SMS) which includes the following functional requirements: 1.4.4 Procedures for reporting accidentsand non-conformities with the provisions of this Code". In the recommendations for implementation, it is underlined that the SMS should require the master to report the following to the designated persons ashore:

- accidents

- hazardous occurrences

- non-conformities within the SMS

- suggested modifications and improvements to the SMS

With regard to the analysis of the reports it is stated that the evaluation of reports may result in:

- corrective action being taken;

- distribution of experiences throughout the company;

- amendment to existing SMS procedures and instructions;

- the development of new SMS procedures.

IMO News (The magazine of the International Maritime Organization) Number 4, 1999 informed among others concerning casualty reports and casualty analysis:

"Casualty statistics are prepared using casualty data submitted by countries to the Organization. This includes statistics on casualties of fishing vessels and fishermen and preliminary information on very serious casualties from rescue co- 
ordination centres." It shall be added that due to very different practices among member countries with regard to reporting procedures and practices, it was decided to establish a Code, later on called the Code for the Investigation of Marine Casualties and Incidents. A joint ILO/IMO as hoc working group on investigation of human factors in maritime casualties agreed draft guidelines on the investigation of the human factor in maritime casualties and incidents, which were submitted to the Maritime Safety Committee. (MSC)

\section{What is then the situation in Namibia?}

Although the requirement of reporting accidents is implemented and underlined by circulars and lettersto companies, the reporting appears casual. Less serious accidents or incidents are reported too late. The findings in this respect revealed in 1997 may be relevant for the situation as in 2001. The following accidents reported to the Directorate Maritime Affairs during the period June 2000 to January 2001 mayillustrate the situation:

- 12 June 2000 on board a trawler, during hosting of trawl doors, the trawl which brakes failed causing the wire to speed out. One man was caught by the wire, dragged into sea and disappeared.

- 6 June 2000 a rock lobster vessel sank while moored. No casualties.

- 1 August 2000 a South African fishing vessel burnt out and sank in Namibian water. No casualties.

- 9 September 2000 a vessel apparently received bunkers illegally offshore causing an oil spill, and at the same time dumped garbage such as wires, mining hoses and empty drums. The master informed that "he was given permission by his head office" to do so.

- 6 October 2000 on board a fishing vessel, a fisherman was dragged over board by some "loosenetting". He disappeared and drowned probably 30-40 meters away from the ship's side whilethe crew was looking on.

- On the 20 October 2000 a large foreign ship was inspected while at anchorage and found un- seaworthy. Detention order was issued, however, the master managed to lift the anchor and sailbefore the vessel could be detained. It is reason to believe that the master was warned. Unfortunately, means to stop the ship leaving Namibia waters were not available.

- 17 October 2000 a Namibian fishing vessel detained in Cape Town on the reasons of "that the vessel places an undue risk of harm to the environment in that the Oily Water Separator equipment has not been surveyed in the past 3 years as required by MARPOL."

- 8 November 2000 a vessel under way caught fire and sank. No casualties.

- 17 January 2001 a vessel under way to the fishing area grounded. No casualties. During an attempt to tow the vessel back to port she sank.

- 2 January 2001 on board a fishing vessel; while "shooting away longlines" a fisherman was entangled with his arm in the rope. The arm broke. Report of the accident only received 17 January, 2001.

- 19 December 2000 while a vessel was alongside a berth in Angola, one of the crew fell into a hold and later on died of the injuries. Directorate Maritime Affairs only informed of the accident18 January 2001.

- 22 January 2001 on board a fishing vessel, a fisherman was caught by the rope while "shootingfishing line" and dragged over board. Luckily the crew managed to get him on board again before he drowned.

When analysing the accidents and incidents as reported above, there are following issues which are apparent:

- Safety training and safety attitudes on board is not good enough

- Management's active involvement in safety training and attitudes must be improved.

- Reports of incidents and accidents are received too late.

- Present legal instruments are not good enough to handle the cases fast and efficient,

- Marine resources in the present situation are not adequate to stop culprits at sea.

\section{Results}

In 1997 the Classification Society, Det Norske Veritas (DNV) was engaged to carry out a maritime safety assessment of the Namibian fleet. The project was basically a fact finding mission to assess the general condition of ships flying the Namibian flag, focusing upon the safety of ships and crew, and pollution prevention. At that time the total number of Namibian registered vessels over 25 G.R.T was: 241 vessels, of which 223 were fishing vessels. A total of 40 vessels were inspected with findings of non-compliance with regulations as shown in Table 1 and Figure 1 . It shall be noted that the inspection carried out was not with the purpose of preventing vessels for sailing or operations, just to establishfacts as to the condition of the inspected vessels.

\begin{tabular}{|c|l|c|c|}
\hline & Category of areas inspected and faults were found & Sum & $\%$ \\
\hline 1 & Ship certificates & 5 & 2 \\
\hline 2 & Lifesaving appliances & 61 & 33 \\
\hline 3 & Firefighting equipment & 49 & 26 \\
\hline 4 & Navigational equipment & 5 & 2 \\
\hline 5 & Safety in general & 57 & 31 \\
\hline 6 & Accommodation & 9 & 5 \\
\hline 7 & Miscellaneous & 2 & 1 \\
\hline
\end{tabular}

Table 1: Fishing vessels inspected 


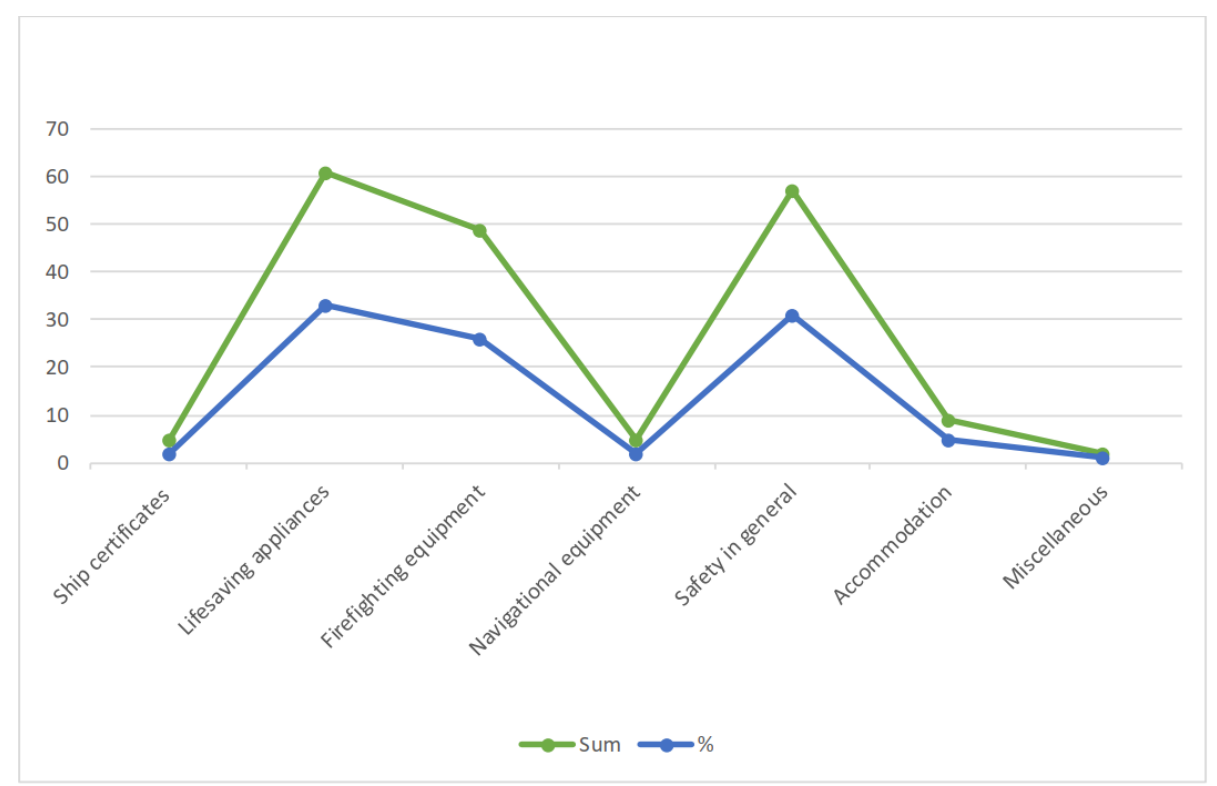

Figure 1: Fishing vessels inspected

It shall be noted that most failures were found in the areas concerning lifesaving appliances, firefighting equipment and safety in general and the report stated: "'In a wider perspective it might be mentioned that this conclusion is quite in line with the overall world-wide distribution of the different categories of deficiencies of vessels inspected by Port State Controls; as a thumb rule, the sum of these three categories are representing the majority of deficiencies reported. With regard to accident reporting, thereport revealed following: "As far as the project team could see, no formal system for accident reporting to the maritime administration was administered. Casual questioning revealed the following recent cases of accidents (not reported):

- One case of flooding of forecastle, caused by damaged (or lack of) forecastle hatch covers.

- Two cases of engine room fire caused by cracks in high pressure pipes to fuel valves for mainengine, which was ignited by splashing on exhaust manifold.

- One case of engine room fire, details unknown.

- One case of finger cutting with fish net handling.

- One case of slipping of mooring spring, where a leg was wounded.

- Two persons drowned.

An investigation of occupational accident rate per 1000 workers in Namibia, covering a total of 24 classes of economic activities, published in April 2000, revealed following as shown in Table 2 and Figure 2 and 3.

\begin{tabular}{|c|l|c|c|c|c|}
\hline \multicolumn{2}{|l|}{ Class of economic activity } & \multicolumn{2}{|c|}{ Accidents } & \multicolumn{2}{c|}{ Injuries } \\
\hline Code & Economic activity & $\begin{array}{c}\text { Total } \\
1000 \\
\text { workers }\end{array}$ & $\begin{array}{c}\text { Fatal } \\
100 \\
\text { workers }\end{array}$ & $\begin{array}{c}\text { Total } \\
1000 \\
\text { workers }\end{array}$ & $\begin{array}{c}\text { Fatal } \\
1000 \\
\text { workers }\end{array}$ \\
\hline 00 & Government services & 14 & 0.20 & 14 & 0.20 \\
\hline 01 & Agriculture \& forestry & 22 & 0.25 & 22 & 0.25 \\
\hline 02 & Fishing & 172 & 8.04 & 172 & 8.04 \\
\hline 03 & Mining & 41 & 0.07 & 41 & 0.07 \\
\hline 04 & Building \& & 87 & 0.97 & 87 & 0.83 \\
\hline 08 & Lonstruction & 153 & & 153 & \\
\hline 13 & Iron and steel & 77 & & 77 & \\
\hline 17 & Transport & 72 & 0.60 & 72 & 0.60 \\
\hline
\end{tabular}

Table 2: Occupational accident rate per 1000 workers in Namibia according to class of economicactivity 


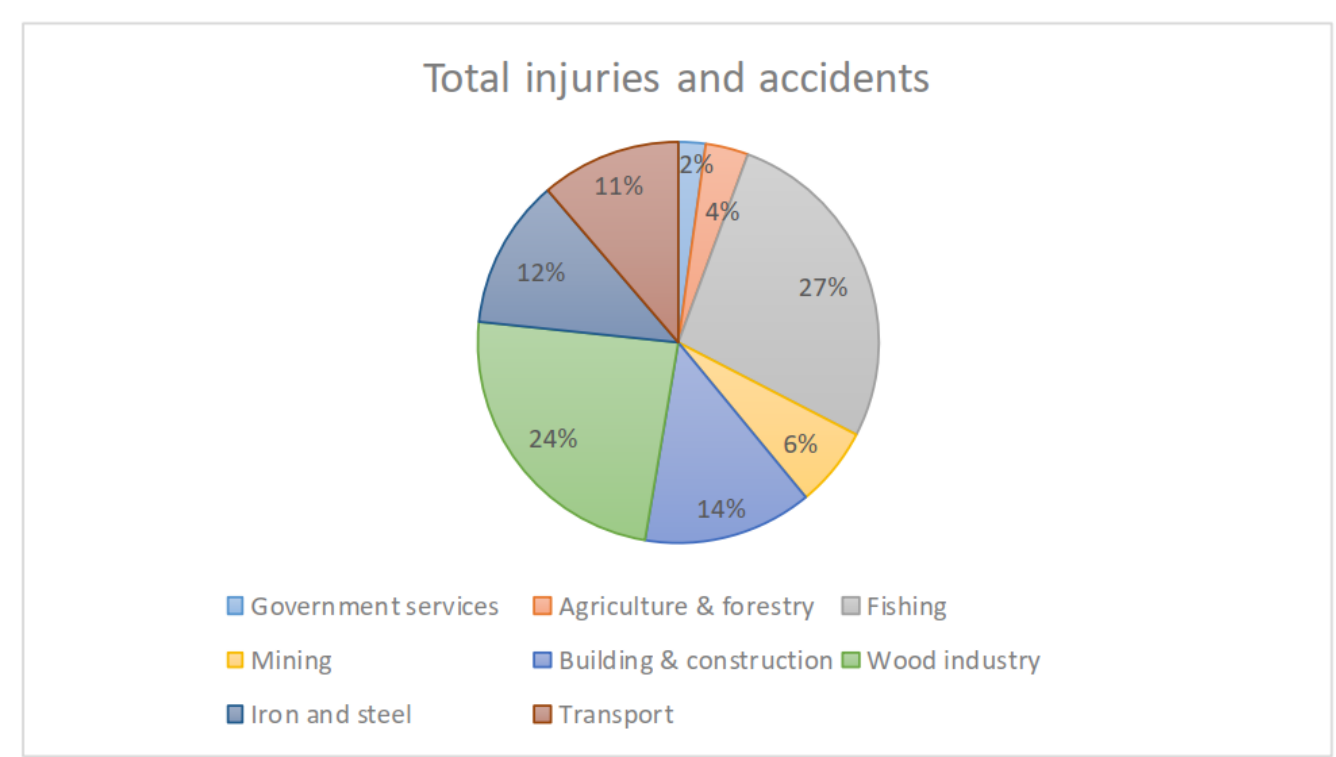

Figure 2: Total injuries and accidents

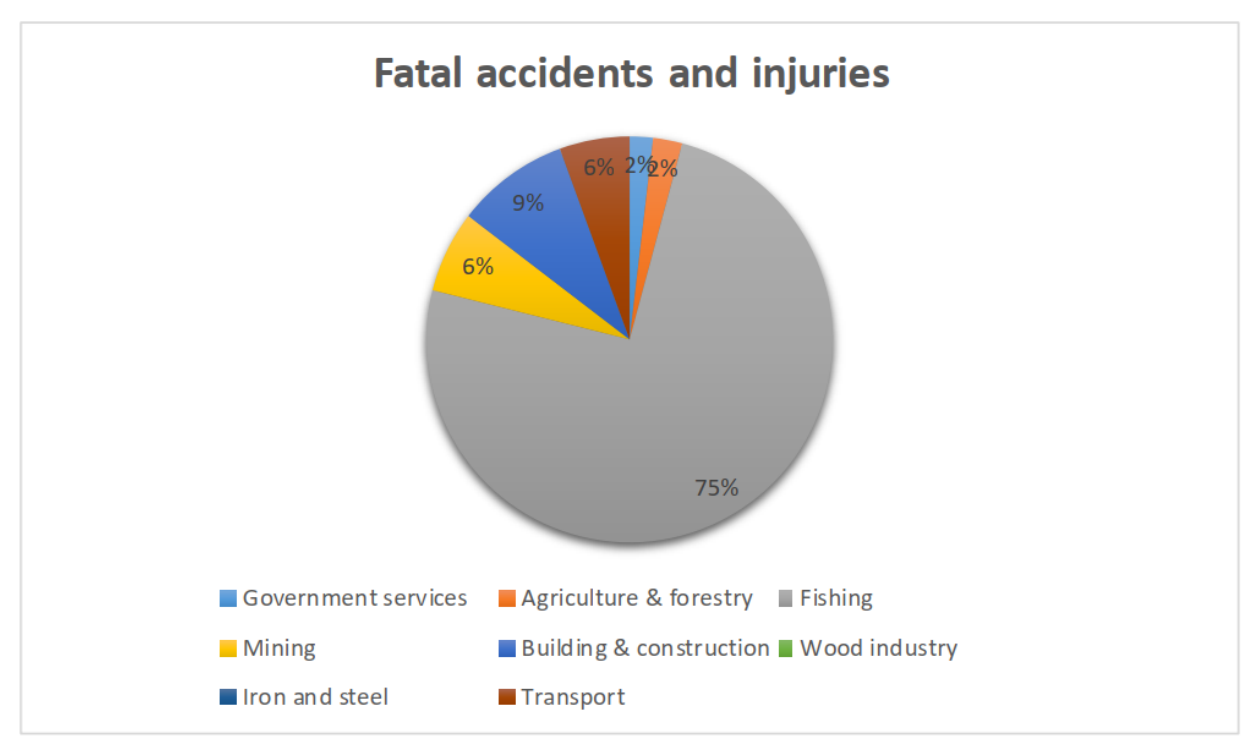

Figure 3: Fatal accidents and injuries

Figure 2 and 3: Occupational accident rate per 1000 workers in Namibia according to class ofeconomic activity

According to class of economic activity represent so many accidents as the fishing industry, even when compared with normally high risk activities mining, building and construction and iron/steel industry. This should have got the alarm bells ringing (Burkhardt K. R. \& Damases R.: Statistical Survey, Occupational accidents in Namibia, 1990-1991). Another interesting information from the same report, shows that occupational accidents in the fishing industry, registered with Workmen's Compensation Commissioner, counts 64, while industries as mining count 585, building and construction 632, iron and steel 466. As pointed out in the same report, accidents reports have been inaccurate due to ignorance, delays and a tendency to report only serious accidents. This complies to a certain degree with the findings in 1997 in the fleet. On this background it shall be noted that the 2007 Labour Act: Regulations on Health and Safety of Employees at Work, requires that all occupational accidents other than road traffic accidents are to be reported to the Ministry of Labour, Industrial Relations \& Employment Creation and the Social Security Commission currently read with the Employees' Compensation Act, 1941 (Act No. 30 of 1941) as amended (Regulations relating to the Health and Safety of Employees at work, made under schedule 1 (2) of Labour Act, 2007 (No. 11 of 2007). As per 15 February 2001, the Namibian fleet over 25 G.R.T consists of following units:

Fishing vessels: 233

Mining vessels: 12

Tugs: 5

Research and patrol: 5

The age of the fleet is as follows:Vessels built before 1980: 207 
Vessels built between 1980 and 1990: 38

Vessels built between 1990 and 2000: 10

The age of a ship or vessel will not automatically determine if it is a high risk vessel or not. In many instances we will find that an older vessel may be far better maintained than a newer vessel, thus representing less chances for accidents than the newer one. An accident on board is most likely to occur due to human error, either by the seaman himself, or wrong management decisions. IMO has long ago reported that at least $80 \%$ of all accidents at sea are due to human errors. What we know is that personnelworking on board fishing vessels are more exposed to dangerous situations than personnel on board cargo carriers. Despite this fact, international maritime conventions have basically been directed at the safety on board merchant shipping vessels, and not the fishing fleet, until we got the Torremolinos Protocol and the International Convention on Standards of Training, Certification and Watchkeeping for fishing vessel personnel, 1995. Only two countries have acceded to this Convention so far, however,it shall be noted that 74 governments were represented when the convention became a reality. (Decisions by the IMO Assembly's $16^{\text {th }}$ session, the Maritime Safety Committee's $62^{\text {nd }}$ session and the IMO Council's $70^{\text {th }}$ session).

\section{Discussion and conclusion.}

Namibia has gone long way since 1990 to develop and maintain a maritime administration able to cope with a modern shipping and fishing industry. However, there is still a long way to go. It is beyond reasonable doubt that the Merchant Shipping Act No. 57 of 1951 as amended in 1991, does not provide regulatory instruments relevant to the requirements of international maritime Conventions. Neither does it provide the Directorate Maritime Affairs strong enough legal response to obvious breach of law. Chapter IX, sections $312-313$ provides penalties for offences between N\$ 80 and 4000 and maximum imprisonment up to 3 years. It is obvious that the monetary penalties are "pocket money" for those who want to omit the law. It shall be kept in mind that the maritime administration shall not only enhance the awareness and positive attitudes in the industry with regard to safety of life at sea and the preventionof pollution of the marine environment, - the administration shall also have the authority and power to bring offenders of the law to court. Experiences proves that without proper legal response to offences, requirements to safety have minor impact on the attitude of some operators. It is interesting to note that representatives of the industry have voiced reluctance to accept the Directorate's efforts to implement for example the requirements of the STCW-78/95 and the STCW-F Conventions. These two Conventions are probably the most important instruments ever agreed on internationally to improve thesafety standards of seafarers. It shall be noted that these safety standards are the minimum agreed on. Representatives from the shipping and fishing industry have participated in development of new maritime legislation through a legal ad hoc committee. This includes Fishing Vessel Construction Regulations, Radio Regulations and Manning of Ships Regulations. Participation of the Industry in enhancing the safety on board ships and vessels is necessary, however, only to a certain extent. If discussions reach a level where a positive development cannot be achieved, it is the government's duty to ensure that required legislation is in place to comply with international standards in this connection. The Republic of Namibia is committed to comply with international standards in maritime affairs. The 3 first Conventions are acceded to, and 6 more will follow during 2001. The objectives of the DirectorateMaritime Affairs, besides the safety at sea and protection of the marine environment, also to promote the maritime interests of Namibia. A basic element for this promotion is to prove to the international maritime community through IMO, that the provisions of relevant Conventions are taken seriously andwill be enforced. To speed up the process of implementing a new maritime accident and reporting system it is recommended that:

- revision of the Marchant Shipping Act is given priority to get it in line with international maritime Conventions;

- a working group consisting of various stake holders and the Government is established with theobjective to formulate reporting routines on board and in the shore based managements concerning accident, near-accidents and incidents representing a hazard both with regard to safety and the marine environment;

- formal cooperation between the Directorate Maritime Affairs and other Governmental bodies relevant for analysing accidents in view of both the 2007

- Labour Act and the maritime regulations;

- strengthening of the safety training of new seafarers with emphasis on awareness and for officers, duty to report;

- workshops should be arranged for officers in the fleet regularly and in cooperation with the industry and the Namibia Maritime and Fisheries Institute where safety issues on board are focus;

- a permanent group should be established within the Ministry/DMA with the objective to analyse accidents, near accidents and incidents, on permanent basis. The group should also prepare relevant documentation for reporting IMO.

The maritime Namibia is relatively young. However, operating the biggest fleet of fishing vessels in the southern hemisphere represent responsibilities both with regard to reputation internationally, and even more important, responsibilities toward the $5-6000$ seafarers on board the fleet. We have not much time available for consideration in this respect, if our credibility both national and international shall not be questioned.

\section{References}

[1]. African Newsletter on Occupational Health and Safety, Volume 10, number 1 April 2000.

[2]. Burkhardt K. R. \& Damases R.: Statistical Survey, Occupational accidents in Namibia, 1990-1991.

[3].Guidelines on the application of the ISM Code (ISF/ICS)

[4].Regulations relating to the Health and Safety of Employees at work, made under schedule 1 (2) of Labour Act, 2007 (No.11 of 2007). 
[5].Social Security Act, 1994 (Act No. 34 of 1994), currently read with the Employees' Compensation Act,1941 (Act No. 30 of 1941) as amended.

[6].The Magazine of the International Maritime Organization Number 4, 1999

[7].The Merchant Shipping Act No. 57 of 1951, as amended in 1991.

[8].The International Convention on Maritime Search and Rescue (SAR), 1979

[9].The International Convention on Standards of Training, Certification and Watchkeeping, 1978 as amended in 1995.

[10]. The International Convention on Standards of Training, Certification and Watchkeeping for Fishing Vessel Personnel, 1995.

[11]. The International Safety Management Code.

[12]. The SOLAS Convention of 1974 and its Protocol 1988.

[13]. United Nations Convention on the Law of the Sea

Dr. Moses Amweelo as a Namibian Member of Parliament from 2000 until $21^{\text {st }}$ March 2015, served as a former Chairperson of the Parliamentary Standing Committee on Information and Communication Technology (ICT). He has served as the Namibian Minister of Works, Transport and Communication from 2000 to $21^{\text {st }}$ March 2005 . He is currently a guest lecturer at the University of Namibia's Engineering Campus in Ongwediva. 